\title{
CHROMOSOME NUMBERS IN SOME ANGIOSPERMS
}

\author{
By \\ Goichi Nakajima \\ Tochigiken Normal School, Utsunomiya
}

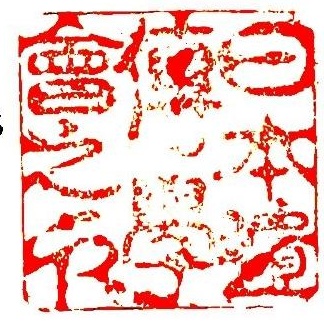

(Received Noi'. 2, 1932)

Counts for the reduced number of chromosomes were made in P. M. C.-s, and for the somatic one in root tip cells. CArnoy's fluid was employed for the fixation of anthers. The root tips were always taken from plants cultivated in pots. In Heluniopsis oricntalis Koldz., Anemone laevigata Kondz., Kerria japonica DC., Clematis heracleaefolia DC., Coptis japonica Makino., Cimicifuga foetida L., Reineckia caprea Kunth., Smilax Sieboldi Mro. and four species of Dioscorca, the root tips were fixed with Nawaschrn's solution, but in all other plants they were fixed with Flemming's medium solution.

All fixed materials were imbedded in paraffin, cut $15^{-1} 8 / \%$ thick, and stained with Herdenhain's iron-alum-haematoxylin.

The figures were drawn on a drawing stand as well as on the plane of the table by the aid of ABBE's large camera. For Figs. I-3, 2I-22, LeITZ I/I 2 oil immersion and ZEISS $\times$ I 5 compensation ocular were used, and for all the remaining Figs. ZeIss apochromatic objective $\mathrm{I} .5 \mathrm{~mm}$ and ZeIss $\times$ I 5 compensation ocular.

Magnifications are $\times 2500$ for Figs. I-3, 2I-22, 26-27, $\times 2270$ for Figs, 6-8, II-I, 23 , and $\times 3000$ for Figs. 4-5, 9-10, 19-20, 24-25, 28.

\section{RESULTS}

Physalis Alkekengi L. var. Francheti Makino.

$2 \mathrm{n}=24$ (Fig. $\mathrm{I}$ )

According to De Vilmorin and Simonet (1928) and Yamamoto and SAKar (1932) the reduced number is invariably 12. My own counts correspond to the results given by the previous authors. 24 chromosomes were clearly seen in root tip cells.

Celastrus articulatus Thunb. $\mathrm{n}=23$ (Fig. 2)

23 chromosomes varying slightly in size were observed in first metaphase. 

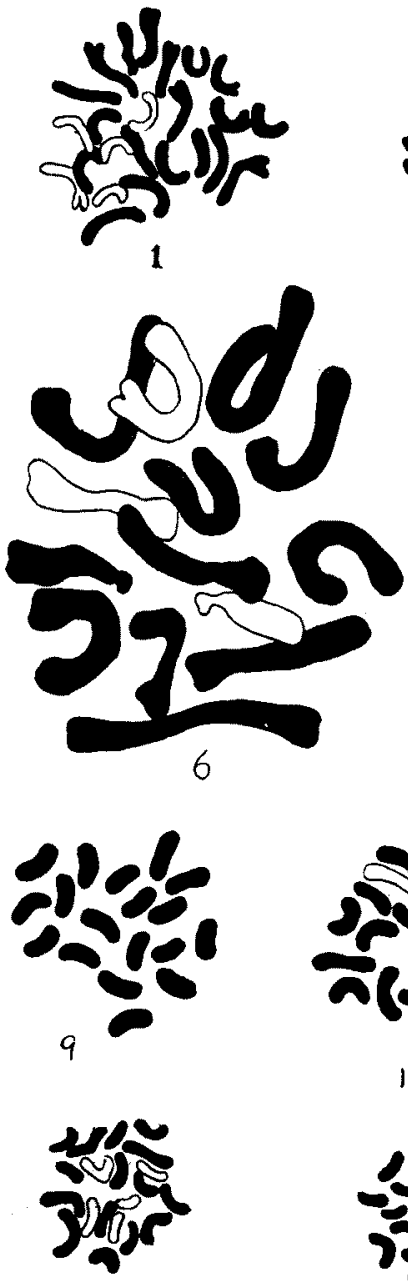

13

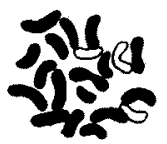

14

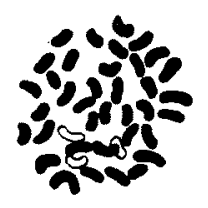

15 16
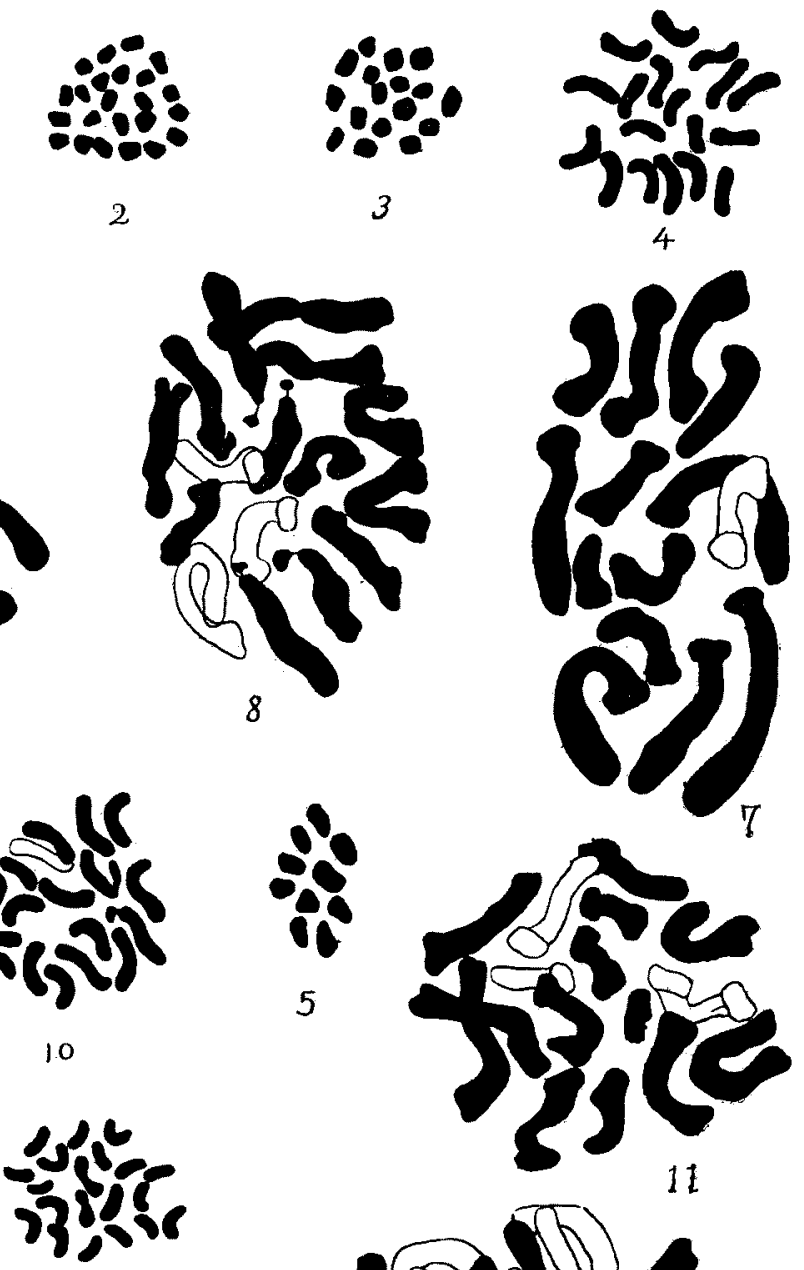

12

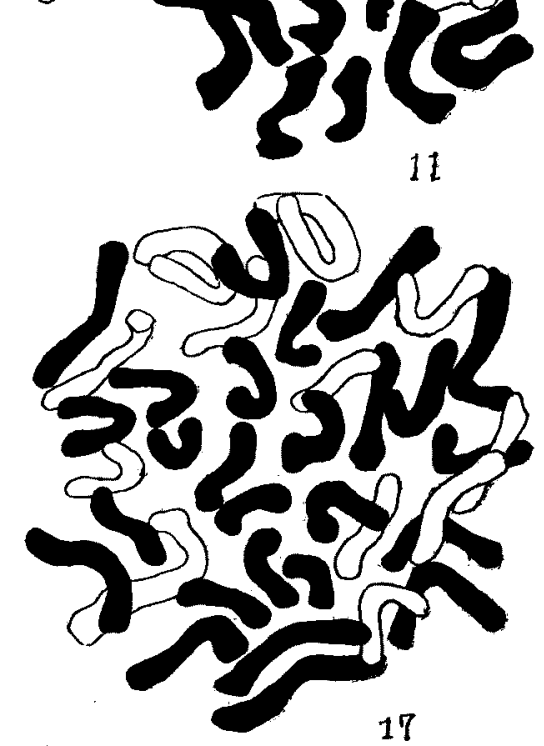

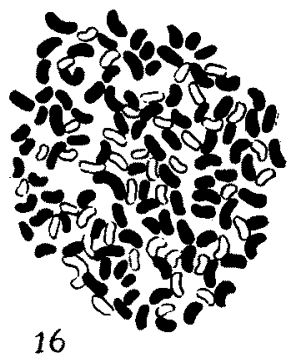




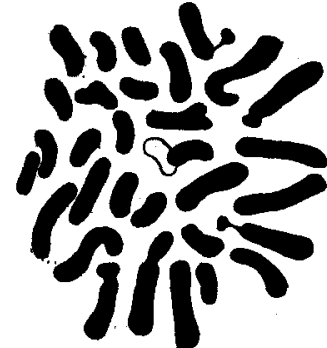

18

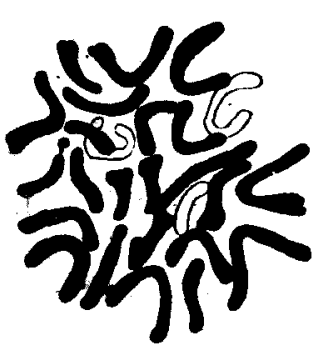

21

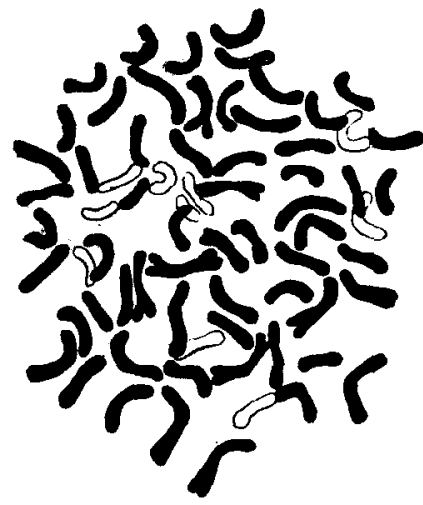

28

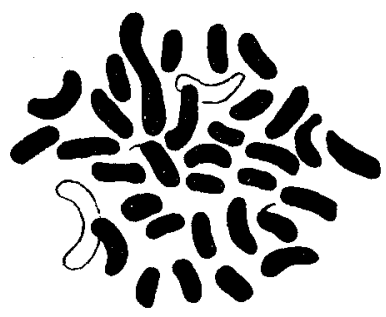

19
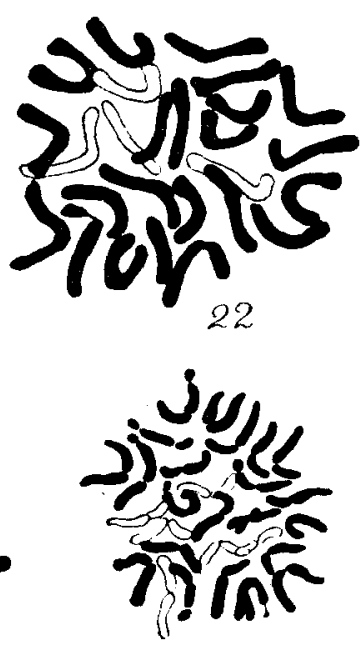

23

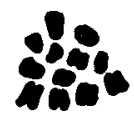

25

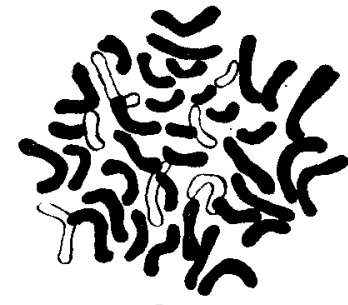

20
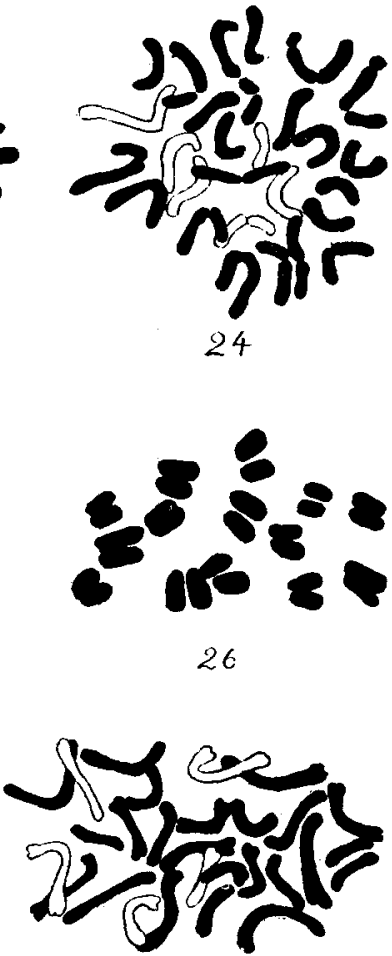

27

Chaenomeles Maulei Lavall.

$$
\mathrm{n}=\mathrm{I} 7 \text { (Fig. 3) }
$$

I 7 small chromosomes were observed in heterotypic metaphase. Kerria japonica DC. var. typica MAKINo.

$$
2 n=18 \text { (Fig. 4) }
$$

I 8 curved or rod shaped somatic chromosomes were observed.

Drosera rotundifulia $\mathrm{L}$.

$$
\mathrm{n}=\mathrm{IO}(\mathrm{Fig} \cdot 5)
$$

The reduced number was reported by BEHRE (1929) to be IO. My counts in second metaphase gave the same result.

Anemone hepatica L.

A. lavigata KoInz.
$2 \mathrm{n}=\mathrm{I} 4$ (Fig. 6)

2n $=14($ Fig. 7$)$ 
Langlet (1927) reported that the reduced number in $A$. hepatica is 7 .

My somatic counts correspond to this. In $A$. laevigata Koidz. the somatic chromosomes were very large.

Clematis heracleaefolia DC. var. stans O. Kunrze. $\quad$ o $2 \mathrm{n}=\mathrm{r} 6$ (Fig. 8)

I6 somatic chromosomes were observed in male plants. Four chromosomes have each a satellite at the terminal end. A satellite of one of these chromosomes seems to be larger than any of the other three.

Coptis japonica Makino. of $2 \mathrm{n}=\mathrm{I} 8$ (Fig. 9) 우 $2 \mathrm{n}=18$ (Fig. Io)

I 8 somatic chromosomes were observed in male and female plants.

Cimicifuga foetida L. var. internedia REGEL. $\quad 2 n=16$ (Fig. II)

LANGLET (1927) reported that the somatic number is I6 in C. foetida, L. I observed 16 large somatic chromosomes of varying size in this variety.

Dioscorea Tokuro Makino.

D. gracillima Mig.

D. japonica Thuns.

今 $2 \mathrm{n}=20$ (Fig, I2)

D. Batalas DECNE.

$$
\begin{aligned}
& \text { 今 } 2 \mathrm{n}=20 \text { (Fig. I3) 우 } 2 \mathrm{n}=20 \text { (Fig. 14) } \\
& \text { 今 } 2 \mathrm{n}=40 \text { (Fig. 1 5) } \\
& \text { 今 } 2 \mathrm{n}=\text { ca. } 140 \text { (Fig. I6) }
\end{aligned}
$$

According to Meurmax (1925) the reduced number of $D$. sinuata was 17 in male plants, and that in D. caucasica IO. I counted 20 small somatic chromosomes in male plants of $D$. Tokoro MAK. and also in male and female plants of $D$. gracillima Mro.. In male plants of $D$. japonica Thuns. I observed 40 small somatic chromosomes. In D. Batatas DECNE. the number of somatic chromosomes could not be decided precisely, as it was very numerous. About 140 chromosomes were counted in somatic cells of male plants. The chromosomes of the four species given above were all rod shaped and small in size.

So far as the present investigations are concerned, the numbers of chromosomes in Dioscorca are the multiples of IO. The results of observation on the sex chromosomes in these four species will be reported later.

Reineckia carnea KunTH. $2 \mathrm{n}=38$ (Fig. I7)

$3^{8}$ large curved or rod shaped somatic chromosomes of similar size were observed.

Smilax Sieboldi MrQ.

$$
2 \mathrm{n}=32 \text { (Fig. } 18 \text { ) }
$$

32 curved or rod shaped somatic chromosomes of varying size were counted clearly. Two of them are provided with satellites.

Heloniopsis orientalis Koldz.

34 rod shaped somatic chromosomes of varying size were observed. Two of them have a terminal appendage (a headless trabant) at one end, which is called "seta" by Kihara (I93I).

Colocasia antiquorm Schort. var esculentum Schотт. $2 \mathrm{n}=42$ (Fig. 20)

42 rod shaped or curved somatic chromosomes were observed.

Amorphophallis Konjac C. КосH.

$2 n=26$ (Fig. 2I) 
26 curved somatic chromosomes were observed.

Arisaema serratum Schотт. $\quad$ o $2 \mathrm{n}=26$ (Fig. 22)

A. Thunbergii Blume. $\hat{o} 2 \mathrm{n}=28$ (Fig. 23) 우 $2 \mathrm{n}=28$ (Fig. 24)

26 curved or rod shaped somatic chromosomes were observed in male plants of $A$. serratum. In $A$. Thunbergii 28 slender somatic chromosomes were observed in male and female plants. The chromosomes of the latter species seem to have a median or submedian constriction. Some possess one more terminal constriction.

Aconis gramineus SolaND.

$$
\mathrm{n}=12 \text { (Fig. 25) }
$$

12 reduced chromosomes were counted in homotypic metaphase.

Plialaris canariensis L. $\quad \mathrm{n}=\mathrm{I} 4$ (Fig. 26) $2 \mathrm{n}=28$ (Fig. 27)

The reduced number was reported to be 6 by Avdulow (1928) and Church (1929). My counts in the same species are on the contrary I4 in haploid and 28 in diploid.

Poa pratensis L. $2 n=70$ (Fig. 28)

STÄHLIN (I929) observed the somatic number to be 56 . I counted 70 rod shaped or curved somatic chromosomes in the same species.

In closing the writer wishes to express his hearty thanks to Professor Dr. F. KaGAwA for his kind suggesions and guidance throughout the present investigation.

\section{LITERATURE}

Avpul.ow, N. P., 1928. Dnewn. Wcecojusn. Ssesd. Botan. I ff. (Cited from Tischler, G. 193 I. Tabulae Biologicae Bd. 7.)

Behre, K., I929. Planta, 7.

Church, G. L., 1929. Bot. Gaz. 87.

KIHARA, H., I93r. 植物染色䱏數/研究. 東京.

Langlet, O. F. J., 1927. Svensk Bot. Tidskr. 21. (Cited from Tischler, G. I931. Tabulae Biologicae Bd. 7.)

Meurman., O., 1925. Commentat. Biol. Soc. Scient. Fenic. 2. (Cited from Tischler, G. 1931. Tabulae Biologicae Bd. 7.)

Stählın, A., 1929. Wissensch. Archiv d. Landwirtsch. 1. (Cited from Tischler, G. I931. Tabulae Biologicae Bd. 7.)

VILMORIN, R., DE et Simonet, M., 1928. Zsitschr. f. induktiv. Alsstamm. u. Vererb.-Lehre. Bd. 50. Suppl. 2.

YamaMoto, K. and SAKAI, K., 1932. fapan. Jour. of Genetics, 8. 